\title{
THE NATURAL HISTORY OF PLEURAL EFFUSION AND ORTHOPAEDIC TUBERGULOSIS
}

\author{
F. Harwood Stevenson, Stanmore, England \\ From the Institute of Orthopaedics and Royal National Orthopaedic Hospital
}

Seven years ago two patients with pleural effusion were seen while under treatment for their orthopaedic lesions. They had no evidence of pulmonary disease and their bone focus proved that they had already passed through the stage of haematogenous dissemination. It seemed therefore that something out of the usual sequence of events might be happening, and it was decided to keep a record of all cases observed with pleural effusion, or seen in hospital with a past history of pleural effusion, so that an assessment might be made of the place of this tuberculous complication in the natural history of patients in an orthopaedic hospital.

Since then the records of sixty-three such effusions have been collected. Occasionally more than one effusion or more than one type of effusion has occurred in the same patient.

Table I shows the main sub-divisions of the material.

TABLE I

Circumstances of Effusion

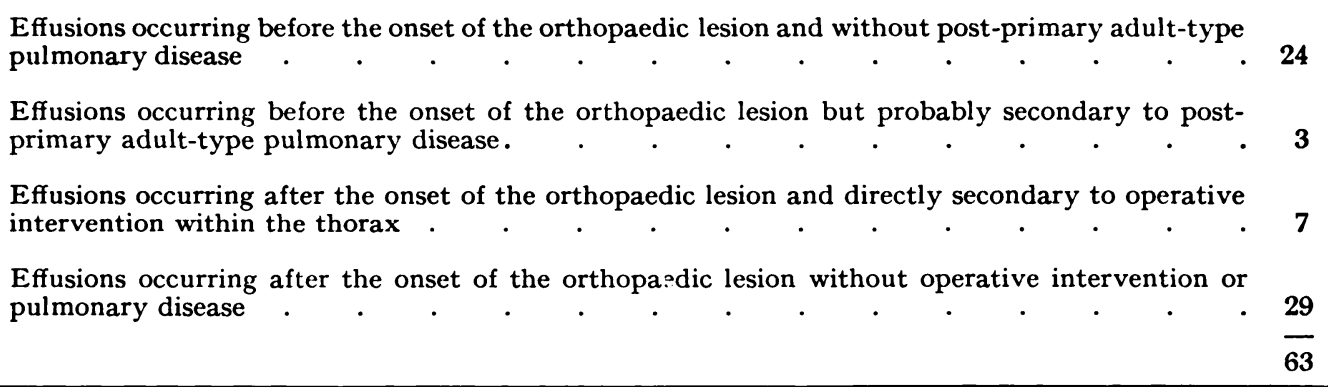

The first two groups of twenty-seven patients who had pleural effusion before the onset of symptoms of the orthopaedic lesion provide a useful comparison with the large fourth group. Their details show that, as might be expected, the vast majority of them - twenty-fourwere probably the immediate post-primary effusions. The orthopaedic lesions developing subsequently as a result of haematogenous dissemination were again, as might be expected, scattered widely throughout the body.

Table II gives details of the twenty-four cases whose effusions have been presumed due to the post-primary haematogenous dissemination.

Table III shows the details of the three patients with pleural effusions secondary to adult-type pulmonary disease.

The bone and joint lesions developing after post-primary effusions and effusions secondary to adult-type or infiltrative pulmonary disease are summarised in Table IV.

Table $\mathrm{V}$ gives the essential histories of the post-operative effusions. They all occurred within one to four weeks of the operation, usually costotransversectomy or antero-lateral decompression of the thoracic spinal cord. In one patient it will be noted that there was a presumptive haematogenous dissemination after a grafting operation on the hip; bilateral pleural effusion occurred three to four weeks later. 
THE NATURAL HISTORY OF PLEURAL EFFUSION AND ORTHOPAEDIC TUBERCULOSIS

TABLE II

Detalls of Twenty-four Cases of Effusion from Post-primary Haematogenous Dissemination

\begin{tabular}{|c|c|c|c|c|}
\hline $\begin{array}{l}\text { Case } \\
\text { number }\end{array}$ & $\begin{array}{l}\text { Year of } \\
\text { birth }\end{array}$ & $\begin{array}{l}\text { Year of effusion and } \\
\text { age at the time }\end{array}$ & $\begin{array}{l}\text { Onset of } \\
\text { orthopaedic } \\
\text { symptoms }\end{array}$ & Site of orthopaedic lesion \\
\hline 2 & 1916 & $\begin{array}{l}1931-25 \text { years. Right effusion. } \\
\text { X-ray } 1951 \text { showed right obliter- } \\
\text { ated costo-phrenic angle but nor- } \\
\text { mal lung fields } \\
1945-29 \text { years. Left effusion }\end{array}$ & December 1948 & $\begin{array}{l}\text { Elbow } \\
\text { Hip and lumbar spine. } \\
\text { Thoracic spine } 9 \text { to } 10 \text { lesion } \\
\text { discovered June } 1949 \text { by cold } \\
\text { abscess seen through heart in } \\
\text { chest } x \text {-ray }\end{array}$ \\
\hline 3 & 1916 & $\begin{array}{l}\text { June } 1937-21 \text { years. Left effusion. } \\
\text { Had right pulmonary lesion }\end{array}$ & December 1937 & Thoracic spine 9 to 12 \\
\hline 4 & 1919 & $\begin{array}{l}\text { September } 1945-26 \text { years. } \\
\text { Right effusion }\end{array}$ & January 1946 & $\begin{array}{l}\text { Thoracic spine } 7 \text { to } 11 \text { with } \\
\text { abscess }\end{array}$ \\
\hline 5 & 1920 & 1946-26 years. Left effusion & 1948 & Lumbar spine 2 and 3 \\
\hline 6 & 1921 & $1948-27$ years & 1950 & Lumbar spine 4 and 5 \\
\hline 7 & 1921 & $1944-23$ years. Left effusion & 1952 & Ankle \\
\hline 8 & 1921 & $\begin{array}{l}\text { April } 1946-25 \text { years. } \\
\text { Left effusion }\end{array}$ & December 1947 & $\begin{array}{l}\text { Lumbo-sacral spine and sacro- } \\
\text { iliac joint }\end{array}$ \\
\hline 9 & 1922 & $\begin{array}{l}\text { 1946-24 years. Left effusion plus } \\
\text { erythema nodosum. } \\
1949-27 \text { years. Right effusion } \\
\text { (see Table VI) and x-ray+bone } \\
\text { disease }\end{array}$ & 1948 & Thoracic spine 8 and 9 \\
\hline 10 & 1922 & $\begin{array}{l}1947-25 \text { years. Left effusion. } \\
1948-26 \text { years. Right effusion. } \\
\text { Infiltration, bilateral apical, in } \\
x \text {-rays } 1950\end{array}$ & 1948 & $\begin{array}{l}\text { Sternum. } \\
\text { Hip }\end{array}$ \\
\hline 11 & 1923 & $\begin{array}{l}\text { 1946_23 years. Right effusion. } \\
\text { 1947_Apical cavity. } \\
\text { 1948_Miliary }\end{array}$ & 1950 & Knee \\
\hline 12 & 1924 & $1939-15$ years & 1948 & Lumbar spine 4 and 5 \\
\hline 13 & 1926 & $\begin{array}{l}1941-15 \text { years. } \\
\text { Chest x-ray } 1951 \text { showed old right } \\
\text { lung primary }\end{array}$ & 1951 & Lumbar spine 4 and 5 \\
\hline 14 & 1926 & $\begin{array}{l}\text { Obliterated right costo-phrenic } \\
\text { angle found nine months after } \\
\text { onset of knee. No history. Pre- } \\
\text { sumed old }\end{array}$ & 1942 & Knee \\
\hline 15 & 1927 & April $1951-24$ years & March 1952 & Lumbar spine 2 and 3 \\
\hline 16 & 1927 & February $1950-23$ years & April 1952 & Lumbar spine \\
\hline 17 & 1929 & July $1932-3$ years. Right effusion & July 1933 & $\begin{array}{l}\text { Discovered thoracic spine } 6 \text { and } \\
7 \text { with abscess and lumbar } \\
\text { spine } 4 \text { lesion }\end{array}$ \\
\hline 18 & 1931 & $\begin{array}{l}1947-16 \text { years. Right and left } \\
\text { pleural effusions and ascites }\end{array}$ & 1951 & $\begin{array}{l}\text { Lumbar spine } 5 \text { and sacral } \\
\text { spine } 1\end{array}$ \\
\hline 19 & 1931 & $1944-13$ years & 1948 & Hip \\
\hline 20 & 1934 & $\begin{array}{l}\text { November } 1949-15 \text { years. } \\
\text { Right effusion. } \\
\text { June } 1950-\text { Pericarditis }\end{array}$ & December 1950 & $\begin{array}{l}\text { Thoracic spine } 12 \text { and lumbar } \\
\text { spine } 1\end{array}$ \\
\hline
\end{tabular}


TABLE II-continued

Details of Twenty-four Cases of Effusion from Post-primary Haematogenous Dissemination

\begin{tabular}{|c|c|c|c|c|}
\hline $\begin{array}{l}\text { Case } \\
\text { number }\end{array}$ & $\begin{array}{l}\text { Year of } \\
\text { birth }\end{array}$ & $\begin{array}{l}\text { Year of effusion and } \\
\text { age at the time }\end{array}$ & $\begin{array}{l}\text { Onset of } \\
\text { orthopaedic } \\
\text { symptoms }\end{array}$ & Site of orthopaedic lesion \\
\hline 21 & $\begin{array}{l}\text { June } \\
1948\end{array}$ & $\begin{array}{l}\text { Small right effusion with primary } \\
\text { on same side }\end{array}$ & November 1949 & Shoulder \\
\hline 22 & 1949 & $\begin{array}{l}1951-2 \text { years. Right effusion plus } \\
\text { soft right primary }\end{array}$ & 1951 & Right subtalar joint \\
\hline 23 & 1949 & $\begin{array}{l}\text { June } 1951-2 \text { years. Right inter- } \\
\text { lobar effusion. Later right calcified } \\
\text { primary seen }\end{array}$ & August 1951 & Thoraco-lumbar spine \\
\hline 24 & - & $\begin{array}{l}\text { Effusion before symptoms. Details } \\
\text { unobtainable }\end{array}$ & 一 & Lumbar spine 4 and 5 \\
\hline
\end{tabular}

TABLE III

Details of Three Patients with Effusion Secondary to Adult-Type Pulmonary Disease

\begin{tabular}{|c|c|c|}
\hline $\begin{array}{c}\text { Case } \\
\text { number }\end{array}$ & $\begin{array}{c}\text { Year of } \\
\text { birth }\end{array}$ & \multicolumn{1}{|c|}{ Clinical details } \\
\hline 25 & 1881 & $\begin{array}{l}\text { Phthisis 1915 and tuberculous greater trochanter. } \\
\text { 1953: Spread from greater trochanter to hip joint. } \\
\text { Chest x-ray: Old left pleurisy and calcified plaques and bilateral apical old disease } \\
\text { December 1947: Bilateral infiltration and left effusion. }\end{array}$ \\
\hline 26 & 1913 & $\begin{array}{l}\text { Onset of orthopaedic symptoms: September 1948. } \\
\text { Site of orthopaedic lesion. Right sacro-iliac joint. Thoracic spine normal } \\
\text { Tuberculous hip and shoulder 1945, and massive primary in right. } \\
\text { Right pleural effusion 1947. Tuberculous empyema drained 1949. No bone source }\end{array}$ \\
\hline
\end{tabular}

TABLE IV

Sites of Thirty-three Lesions in Twenty-seven Patients with Skeletal Disease Occurring After Post-primary Effusions or Effusions Secondary to Adult-type Pulmonary Disease

\begin{tabular}{|c|c|c|c|c|c|c|c|c|c|}
\hline \multicolumn{10}{|l|}{ Spine: } \\
\hline \multicolumn{3}{|c|}{ Thoraco-lumbar } & . & . & . & • & $\cdot$ & • & $\begin{array}{l}5 \\
2\end{array}$ \\
\hline \multicolumn{3}{|c|}{ Lumbar } & . & . & . & . & . & . & 9 \\
\hline \multicolumn{3}{|c|}{ Lumbo-sacral } & . & . & . & . & . & . & 2 \\
\hline Hip & . & . & . & . & . & . & . & . & 4 \\
\hline Ankle & . & - & . & . & . & . & . & . & 1 \\
\hline Elbow & - & . & . & . & . & - & . & . & 1 \\
\hline Sacro-il & ac join & & . & . & - & - & - & - & 2 \\
\hline Sternun & & . & . & . & - & - & - & . & 1 \\
\hline Knee & . & . & . & - & - & - & - & . & 2 \\
\hline Shoulde & & . & . & - & - & - & - & - & 2 \\
\hline Subtala & - joint & . & . & . & - & - & - & - & 1 \\
\hline Greater & trocha & inter & - & - & . & . & . & - & 33 \\
\hline
\end{tabular}


TABLE V

Details of Seven Cases of Post-operative Pleural Effusion

\begin{tabular}{|c|c|c|c|}
\hline $\begin{array}{c}\text { Case } \\
\text { number }\end{array}$ & $\begin{array}{c}\text { Year of } \\
\text { birth }\end{array}$ & \multicolumn{1}{c|}{ Clinical details } \\
\hline 28 & 1905 & $\begin{array}{l}\text { Right effusion ten days after right costotransversectomy 1953 (lung previously clear) } \\
\text { Left costotransversectomy January 1952; three weeks later slightly bloodstained } \\
\text { lymphocytic sterile left effusion. } \\
\text { March 1952 right antero-lateral decompression; five days later a right sterile } \\
\text { lymphocytic effusion. }\end{array}$ \\
30 & 1921 & $\begin{array}{l}\text { Left effusion two weeks after left costotransversectomy 1948. } \\
\text { Left effusion one week after left costotransversectomy 1948 }\end{array}$ \\
31 & 1935 & $\begin{array}{l}\text { Effusion on same side few days after antero-lateral decompression 1952. Pleura } \\
\text { was punctured }\end{array}$ \\
34 & $1937 \begin{array}{l}\text { Tuberculous hip 1941. Grafted 1943 } \\
\text { Bilateral lymphocytic sterile effusions three to four weeks after operation. No } \\
\text { evidence of spinal disease clinically or in chest x-rays. Presumed haematogenous } \\
\text { dissemination. }\end{array}$ \\
\hline
\end{tabular}

\section{PLEURAL EFFUSIONS OCGURRING AFTER THE ORTHOPAEDIG LESION AND WITHOUT PULMONARY DISEASE OR LOCAL OPERATIVE INTERVENTION}

These twenty-nine patients will be seen in Table VI in three groups. The first and largest consists of twenty-three cases. All of these developed their pleural effusion either after the onset of symptoms from a thoracic or thoraco-lumbar tuberculous spondylitis with cold abscess, or actually during the time spent in hospital for treatment of this condition. The

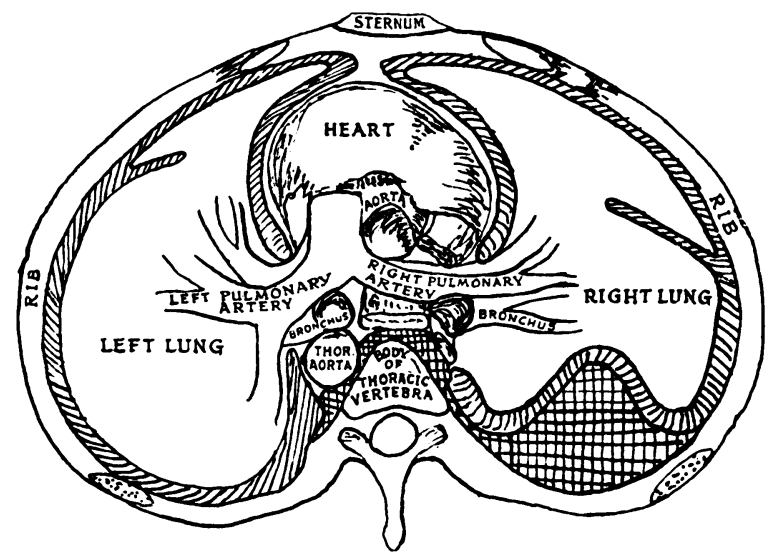

FIG. 1

To show the relationship between the paravertebral region and the outside of the parietal pleura. On the right side an extra-pleural lateral extension of an abscess is shown pushing the pleura and lung forwards as described in the text. The pleural space is shown shaded and the paravertebral abscess cross-hatched.

absence of pulmonary disease makes the fact that their orthopaedic lesion in every case involved the thoracic spine, and therefore lay immediately outside the parietal pleura, highly significant (Fig. 1).

Two more patients, the second group in Table VI, also had thoracic spinal disease but 
TABLE VI

Details of Twenty-nine Cases in which Pleural Effusion Occurred After the Orthopaedic Lesion

\begin{tabular}{|c|c|c|c|c|}
\hline $\begin{array}{l}\text { Case } \\
\text { number }\end{array}$ & $\begin{array}{l}\text { Year of } \\
\text { birth }\end{array}$ & $\begin{array}{l}\text { Year of effusion and } \\
\text { age at the time }\end{array}$ & $\begin{array}{l}\text { Onset of } \\
\text { orthopaedic } \\
\text { symptoms }\end{array}$ & Site of orthopaedic lesion \\
\hline 35 & 1892 & $\begin{array}{l}\text { January } 1952-60 \text { years. } \\
\text { Transient small effusion }\end{array}$ & January 1951 & $\begin{array}{l}\text { Thoracic spine } 11 \text { and } 12 \text { proved } \\
\text { December } 1951+\text { abscess }\end{array}$ \\
\hline 36 & 1903 & \multirow{2}{*}{\multicolumn{3}{|c|}{$\begin{array}{l}\text { Nursed tuberculous sister } 1924 \text { to } 1930 \text { (died). } \\
\text { Pleural effusion left } 1933 \text { ( } 30 \text { years) + pain lower ribs girdling both sides. } \\
1936 \text { discovered thoracic spinal disease with cold abscess mainly projecting to left } \\
42 \text { years. Left pleural effusion four months after costotransversectomy 1947. (Too } \\
\text { late for post-operative causation) }\end{array}$}} \\
\hline 37 & 1905 & & & \\
\hline 38 & 1906 & $\begin{array}{l}\text { December } 1937-31 \text { years. } \\
\text { Right effusion }\end{array}$ & $\begin{array}{l}\text { January } 1937 \text {, } \\
\text { after fall }\end{array}$ & Thoracic spine 8 to 12 +abscess \\
\hline 39 & 1913 & August $1952-39$ years & May 1952 & $\begin{array}{l}\text { Thoracic spine } 10 \text { to } 12+ \\
\text { abscess. + Tarsus }\end{array}$ \\
\hline & & November $1946-30$ years. & 1943 & Thoracic spine 6 and $7+$ abscess \\
\hline 40 & 1916 & $\begin{array}{l}\text { Right effusion proved tuberculous. } \\
\text { Left dry pleurisy }\end{array}$ & 1946 & Lumbar spine 2 to 5 \\
\hline 41 & 1917 & \multicolumn{3}{|c|}{$\begin{array}{l}\text { Tuberculous thoracic spine } 7 \text { to } 12+\text { abscess early } 1952 \text {. } \\
\text { Right costotransversectomy January } 1953 \text {. } \\
\text { Right effusion July } 1953 \text { ( } 36 \text { years), guinea pig }+ \text {, and left August } 1953 \text { (too late for } \\
\text { post-operative causation). }\end{array}$} \\
\hline 42 & 1917 & December $1942-25$ years & \multicolumn{2}{|c|}{$\begin{array}{l}\text { Back symptoms March } 1943 ; x \text {-rays December } \\
1943 \text { show old thoracic spine } 12 \text { and lumbar } \\
\text { spine } 1 \text { tuberculous disease and bony bridging }\end{array}$} \\
\hline 43 & 1918 & $\begin{array}{l}\text { February } 1946-28 \text { years. When } \\
\text { in hospital for treatment of spine }\end{array}$ & 1941 & Thoracic spine 7 to 11 \\
\hline 44 & 1919 & July $1949-30$ years. Left effusion & March 1947 & $\begin{array}{l}\text { Thoracic spine } 8 \text { and } 9 \text { x-ray }+ \\
\text { March } 1948\end{array}$ \\
\hline 45 & 1919 & $\begin{array}{l}\text { September } 1945-26 \text { years. Right } \\
\text { effusion (post-primary) and recurr- } \\
\text { ence right July } 1947 \text { and left May } \\
1948 \text {, both tuberculous }+\end{array}$ & January 1946 & Thoracic spine 7 to $11+$ abscess \\
\hline 46 & 1920 & \multicolumn{3}{|c|}{28 years. Left effusion approximately 1948 in Stanmore with mid-thoracic disease } \\
\hline 47 & 1922 & $\begin{array}{l}\text { July } 1950-28 \text { years. } \\
\text { Right effusion. } \\
\text { Lungs normal. Abscess visible }\end{array}$ & $\begin{array}{l}\text { Under treat- } \\
\text { ment March } \\
1950 \text { to Dec- } \\
\text { ember } 1952\end{array}$ & $\begin{array}{l}\text { Thoracic spine } 12 \text { and lumbar } \\
\text { spine } 1\end{array}$ \\
\hline 48 & 1922 & $\begin{array}{l}24 \text { years. Erythema nodosum and } \\
\text { left effusion } 1946 \text { (post-primary). } \\
\text { Right effusion } 1949 \text { (secondary to } \\
\text { abscess) }\end{array}$ & 1948 & Thoracic spine 8 and $9+$ abscess \\
\hline 49 & 1935 & $\begin{array}{l}\text { September } 1947-12 \text { years. } \\
\text { Lymphocytic right effusion }\end{array}$ & July 1947 & Thoracic spine 9 to $11+$ abscess \\
\hline 50 & 1941 & \multicolumn{3}{|c|}{$\begin{array}{l}5 \text { years. May } 1946 \text { left pleural effusion and at same time found to have large kyphos } \\
\text { and abscess mid-thoracic spine }\end{array}$} \\
\hline 51 & 1947 & April $1952-5$ years & - & $\begin{array}{l}\text { Thoracic spine } 9 \text {. Tuberculosis } \\
\text { +abscess found June } 1952 \text { and } \\
\text { must have been present in } \\
\text { April } 1952\end{array}$ \\
\hline 52 & - & $\begin{array}{l}\text { Costotransversectomy October } \\
1945 . \\
\text { Pleural effusion March } 1946\end{array}$ & December 1943 & Thoracic spine 8 and $9+$ abscess \\
\hline 53 & 1925 & $\begin{array}{l}1944-19 \text { years. Pleural effusion } \\
\text { left and Pott's disease in Army }\end{array}$ & - & Thoracic spine 7 to 12 \\
\hline 54 & 1920 & $\begin{array}{l}\text { July } 1945-25 \text { years. } \\
\text { Right effusion }\end{array}$ & March 1945 & Thoracic spine 10 to 12 \\
\hline 55 & 1924 & October $1953-29$ years & August 1946 & Thoracic spine 8 to 11 \\
\hline
\end{tabular}


TABLE VI-continued

Details of Twenty-nine Cases in which Pleural Effusion Occurred After the Orthopaedic Lesion

\begin{tabular}{|c|c|c|c|c|}
\hline $\begin{array}{c}\text { Case } \\
\text { number }\end{array}$ & $\begin{array}{l}\text { Year of } \\
\text { birth }\end{array}$ & $\begin{array}{l}\text { Year of effusion and } \\
\text { age at the time }\end{array}$ & $\begin{array}{l}\text { Onset of } \\
\text { orthopaedic } \\
\text { symptoms }\end{array}$ & Site of orthopaedic lesion \\
\hline 56 & 1935 & September $1947-12$ years. & July 1947 & Thoracic spine \\
\hline 57 & 1897 & $\begin{array}{l}\text { February } 1947-50 \text { years. Right. } \\
\text { July } 1947 \text {. Left }\end{array}$ & \multicolumn{2}{|c|}{$\begin{array}{l}\text { July } 1947 \text { weakness of the legs and pins and } \\
\text { needles from the waist downwards. July } 1948 \\
\text { readmitted for increasing paraplegia and dis- } \\
\text { covered to have tuberculous thoracic spine } 11 \\
\text { and } 12 \text { with cold abscess. Must have been } \\
\text { present July } 1947 \text { at least. }\end{array}$} \\
\hline 58 & 1905 & February $1950-45$ years. Right & February 1951 & $\begin{array}{l}\text { Discovered radiologically to } \\
\text { have thoracic } 9 \text { and } 10 \text { lesion }+ \\
\text { abscess. No symptoms refer- } \\
\text { able to lesion and ? old. Age } \\
\text { suggests effusion not post- } \\
\text { primary }\end{array}$ \\
\hline 59 & 1920 & \multicolumn{3}{|c|}{$\begin{array}{l}31 \text { years. } \\
1949 \text {-Soft lesion above right costo-phrenic angle. } \\
1950 \text { - Soft lesions right apex and right lower zone. Cold abscess visible through } \\
\text { heart in chest film. } \\
\text { January } 1951 \text { - Pain in the back began. } \\
\text { September } 1951 \text { - Right pleural effusion. } \\
\text { It is not certain whether in this case the pleural effusion was secondary to the } \\
\text { pulmonary lesion or the cold abscess, though the fact that the abscess had some } \\
\text { months previously tracked round to the right and pointed between the ribs strongly } \\
\text { suggests the latter }\end{array}$} \\
\hline 60 & 1929 & May $1948-19$ years & March 1947 & $\begin{array}{l}\text { Sacro-iliac joint. } \\
\text { Thoracic spine never } x \text {-raved }\end{array}$ \\
\hline 61 & 1881 & \multirow{3}{*}{\multicolumn{3}{|c|}{$\begin{array}{l}\text { 1915-Gland in neck. } \\
1931 \text { - Sacro-iliac joint lesion. } \\
\text { August } 1948-\text { Lumbar spine } 2 \text { to } 4 \text {, Addison's disease and tuberculous sacro-iliac joint. } \\
\text { December } 1948-67 \text { years. Clear left effusion. } \\
\text { November } 1949 \text {-Right effusion. } \\
\text { Meningitis, ? ascending, ? haematogenous; died February } 1950 \text {. No post-mortem } \\
\text { Admitted April } 1944: \text { lumbar spine } 4 \text { and } 5 \text {. Left pleural effusion September } 1944- \\
23 \text { years. No evidence of pulmonary or thoracic spinal disease } \\
\text { March } 1947-21 \text { years. Left effusion while in hospital for tuberculous lumbar spine } \\
3 \text { and } 4 \text {. No evidence of pulmonary or thoracic disease. }\end{array}$}} \\
\hline 62 & 1921 & & & \\
\hline 63 & 1926 & & & \\
\hline
\end{tabular}

there was some uncertainty as to the origin of the effusion and though it may have been due to the paravertebral abscess the claim could be made with less certainty.

Case 58-This patient suffered a right-sided effusion at the age of forty-five and was accidentally discovered to have a vertebral lesion at T.9-10 with abscess a year later. There were no symptoms referable to this lesion and it may well have been old and present at the time of her effusion. Her age itself suggests that the effusion was not immediately post-primary.

Case 59-This patient has also been listed in this separate group because she did have pulmonary lesions in the right chest from February 1949 onwards and developed a right pleural effusion in September 1951. The cold abscess could be seen, however, through the heart shadow in the chest radiograph as far back as May 1950 and could well have been the cause of her effusion.

The third group of four patients who developed a pleural effusion after their orthopaedic lesion without evidence either of pulmonary lesions or of thoracic spinal disease contains one patient (Case 60) whose thoracic spine was never in fact radiographed, one (Case 61) who had bilateral effusions fifteen months (left) and three months (right) before death and actually died of meningitis. This may have been ascending or haematogenous. There was no postmortem examination. The last two cases (62 and 63) definitely had pleural effusions while in hospital under treatment for lower lumbar spinal disease only, and in each the thoracic spine was radiologically normal.

vol. 37 B, No. 1, FEBRLARY 1955 
Of the twenty-nine patients in this group, therefore, twenty-three showed no other apparent reason for effusion than the thoracic spondylitis; in two more very probably the same reason held; in a further two, essential details are lacking and only in a final two did effusion certainly occur during conservative treatment for lumbar spinal disease without evidence of thoracic or pulmonary lesions.

The conclusion that may be drawn from these figures is quite clear: when a pleural effusion occurs before the onset of orthopaedic disease or is clearly secondary to pulmonary

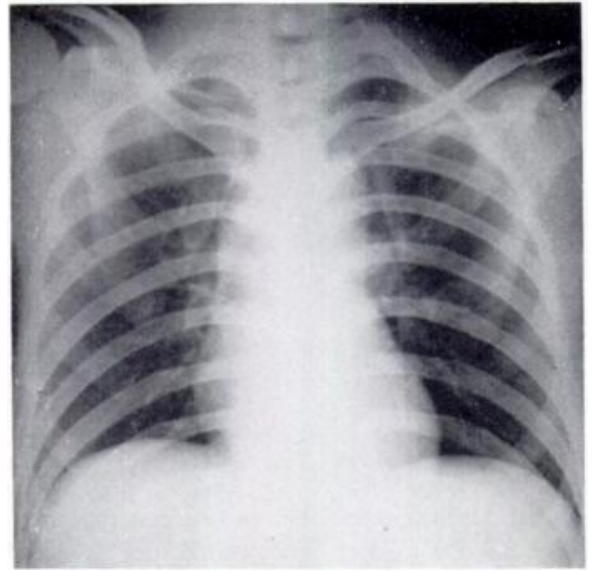

FIG. 2

Case 54--Before effusion.

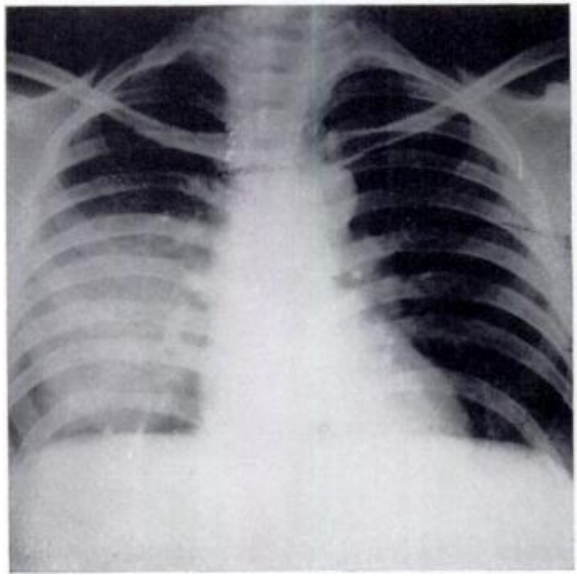

FIG. 4

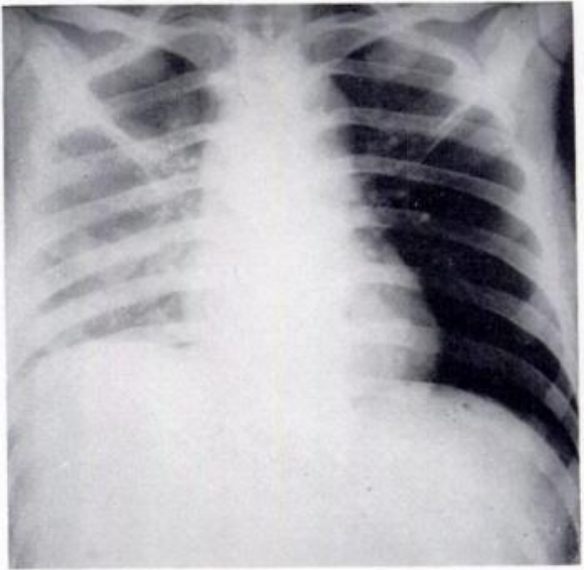

FIG. 3

Case 54-Right pleural effusion.

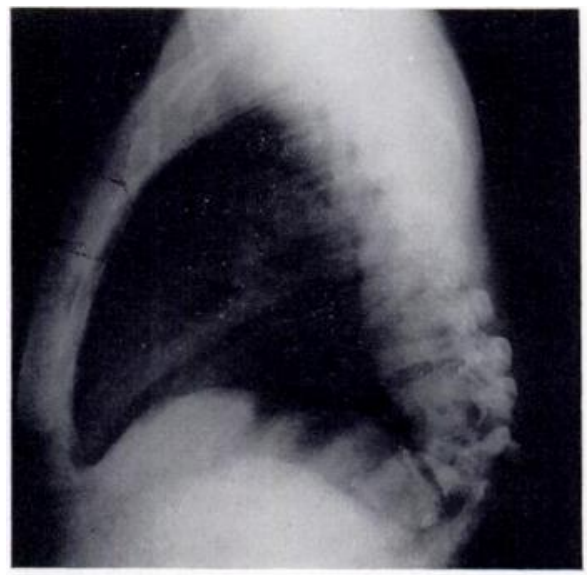

FIG. 5

Case 54-Lateral extension of cold abscess, seen bulging forwards in the lateral view.

disease then the orthopaedic lesion may be anywhere throughout the skeleton (Table IV). But when the effusion arises after the onset of the orthopaedic disease and without a pulmonary cause or immediately preceding operative intervention in the thorax the lesion will almost certainly involve the thoracic spine. It is difficult to avoid the conclusion that this group of pleural effusions occurring after the period of haematogenous dissemination and without pulmonary disease is, in fact, due to the direct spread through the parietal pleura of tuberculous infection from the paravertebral abscess (Fig. 1).

It was surprising to find that there was little variation in the clinical picture produced by these pleural effusions whatever the cause, except in the amount of effusion and the length of time that it took to absorb. This, of course, might be affected, even in large effusions, by 
the decision whether or not to aspirate. In the cases observed, whether they were post-primary, post-operative or during conservative treatment for the orthopaedic lesion, the pyrexia commonly rose and after a plateau gradually fell over a period of three to four weeks. None of the effusions became purulent; the cytology was predominantly lymphocytic. As is common with tuberculous pleural effusions acid-fast bacilli were sometimes grown and sometimes not.

During the time required to collect twenty-five cases of this transpleural infection 145 patients with thoracic or thoraco-lumbar spinal tuberculosis have been seen at this hospital; so in a proportion of approximately one in six a pleural effusion occurred that was not immediately post-primary. Ornstein and Ulmar $(1935,1939)$ believed a thoracic paravertebral abscess to be a not uncommon cause of unilateral and bilateral pleural effusions. Of the standard text-books upon chest diseases, Marshall and Perry (1952) and Pagel, Simmonds and Macdonald (1953) mention the possibility, whereas other well known works do not, and it has not seemed to the writer from conversations with colleagues that the connection was well recognised. In particular, however, this report is offered not to illustrate the fact that the sequence is possible but that in so high a proportion of effusions occurring after the onset of the bone symptoms this relationship is to be expected. Seddon (1936) recorded a case of rupture of a paravertebral abscess into the pleura giving rise to a large tuberculous empyema, but this is an entirely different and much more rare occurrence.

\section{PLEURAL EFFUSION SECONDARY TO LARGE LATERAL EXTRA-PLEURAL EXTENSION OF PARAVERTEBRAL ABSGESS}

There is one sub-group of thoracic paravertebral abscesses which does not appear to have been stressed before. Their behaviour is illustrated in the right side of Figure 1 and the histories in Cases 54, 55 and 56 are given in illustration.

Case 54-This patient developed tuberculosis of the spine at T.10-T.12 in March 1945. Chest radiographs a month later showed normal and equal lung fields with an abscess shadow just visible inside the right border of the heart (Fig. 2). Three months later she developed a right pleural effusion (Fig. 3). Further chest radiographs in July 1948 showed a diffuse shadow occupying the right lower zone, with some translucency both on the medial and lateral sides of it (Fig. 4). This type of shadow, which might well represent an inter-lobar effusion, had been seen before, and lateral radiographs proved that it was in fact due to an abscess bulging forwards from the posterior chest wall (Fig. 5). The abscess was needled three inches from the mid-line in the right lower chest; inspissated pus was withdrawn and guinea-pig inoculation confirmed its tuberculous nature. Case 55-This patient had tuberculous disease of the spine in 1943 which became temporarily quiescent. Chest radiographs in October 1949 showed normal lung fields and the old abscess shadow could just be seen through the heart shadow (Fig. 6). About August 1953 he developed a total pleural effusion on the left side. Radiographs three months later again showed the shadow with increased translucency both medial and lateral to it (Fig. 7). The lateral radiograph showed a large abscess projecting forwards at the level of the spinal lesion (Fig. 8). Needling about three inches from the mid-line yielded pus, proved tuberculous by guinea-pig inoculation. Repeated aspiration has caused a reduction in size of the abscess. Now, four months after admission, the condition is that shown in Figures 9 and 10.

Case 56-The patient in this case developed tuberculous disease of the spine at T.9-T.11 in July 1947. Two months later he had a right lymphocytic pleural effusion. The chest radiographs taken a month before the effusion developed were clear, except for the central paravertebral abscess which could just be seen through the heart (Fig. 11). Radiographs taken one month after the effusion (Fig. 12) showed a condition like that seen in Case 55. The lateral film again showed a large abscess projecting forwards (Fig. 13). Successive aspirations of large quantities of pus finally reduced the abscess to a very small inspissated collection close to the posterior thoracic wall (Fig. 14).

\section{LYMPHATIC SPREAD FROM PLEURA TO LYMPH NODES AND THENGE TO BONE}

A study of pleural effusion and skeletal tuberculosis would be incomplete without discussing the belief that tuberculous pleurisy may be a cause of bone disease by lymphatic spread to ribs and spine. Souligoux (1894) demonstrated the lymphatic connections between the pleura and parasternal lymph nodes, and showed that tuberculous pleurisy, and particularly

vol. 37 B, No. 1, FEBRUARY 1955 


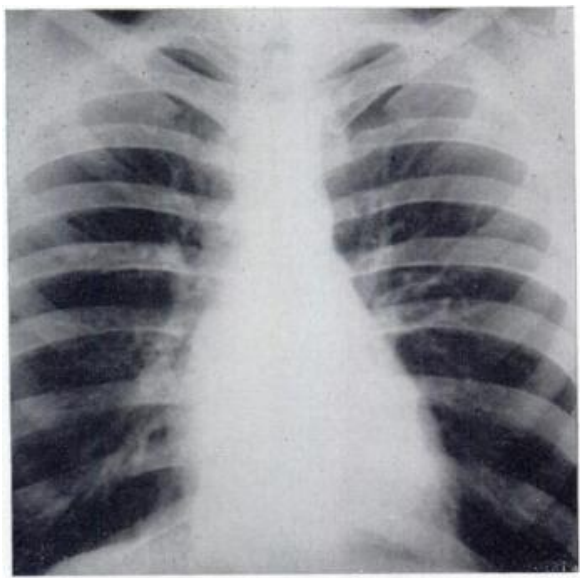

FIG. 6

Case 55-Before effusion.

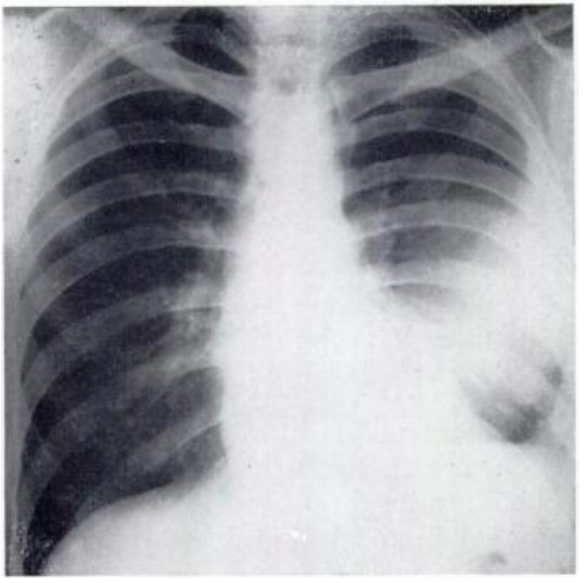

FIG. 7

Case 55-Lateral extension of cold abscess after effusion. The abscess is seen bulging forwards in the lateral view.

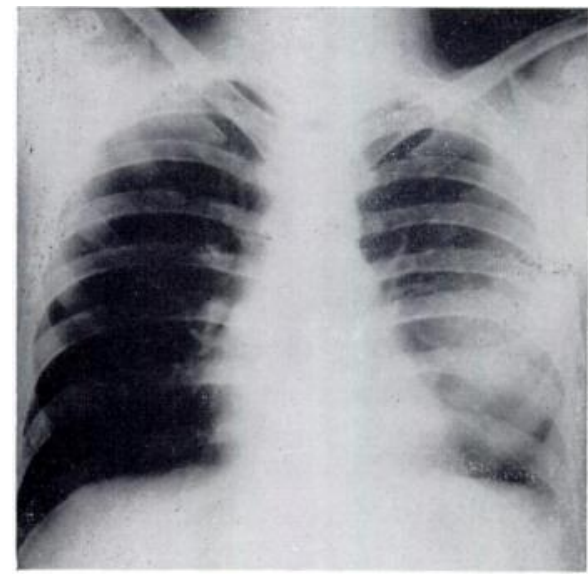

FIG. 9

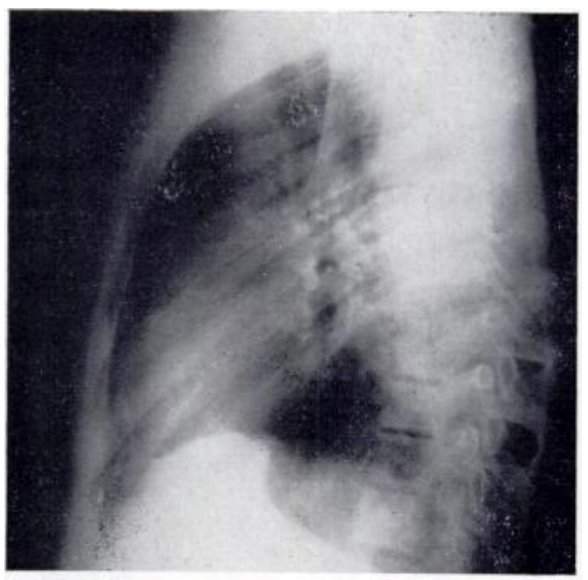

Fig. 10

Case 55-Abscess reduced after repeated aspiration. 
empyema, could produce caseous parasternal lymph nodes. Kaufmann (1930, 1931, 1933) followed by showing that cold abscess of the chest wall could arise from these caseous parasternal lymph nodes. But he also suggested that paravertebral cold abscess and disease of the spine could be secondary to caseous disease of the para-aortic lymph glands, especially in the neighbourhood of the crura of the diaphragm. Both Fraser $(1913,1929)$ and Kaufmann (1936) did demonstrate in a few cases that a caseous tuberculous gland lying against a vertebral

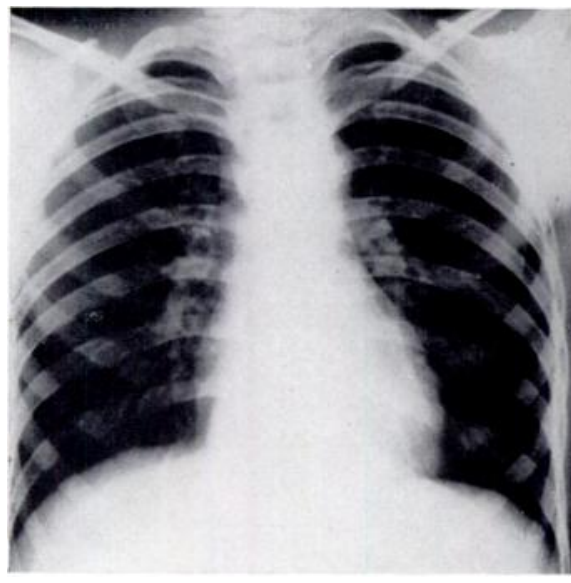

FIG. 11

Case 56. Figure 11-Before effusion

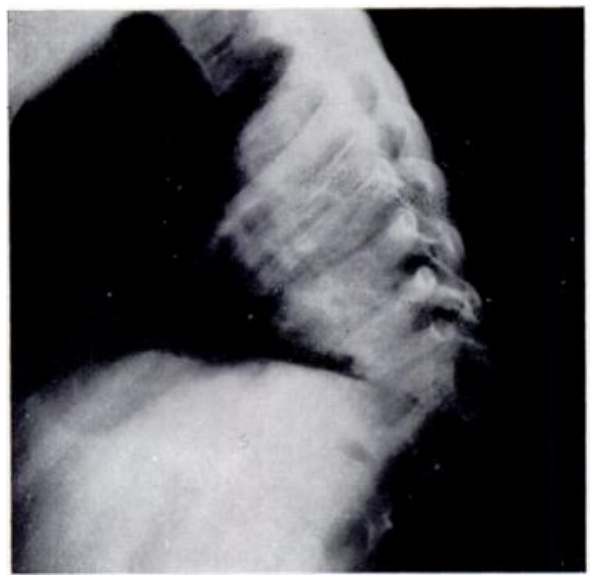

Fig. 13

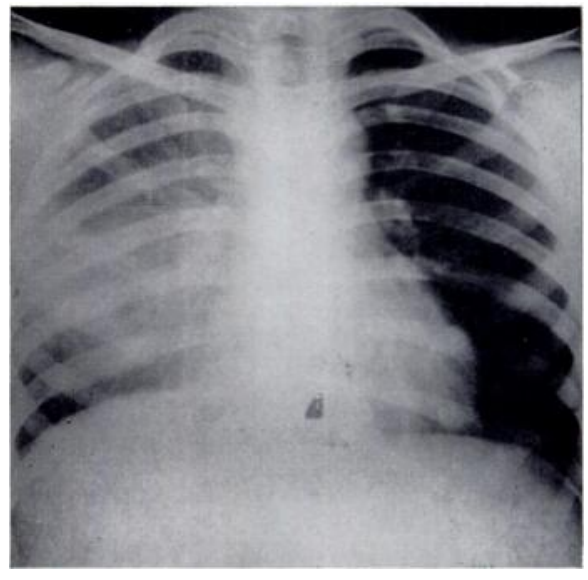

Fig. 12

Before effusion. Figure 12-Lateral extension of abscess after effusion.

Case 56. Figure 13-Same as Figure 12, lateral view. Figure 14-Abscess markedly reduced after repeated aspiration.

body could produce superficial caries of the bone by lymphatic spread through the paravertebral ligaments.

Burke $(1940,1940,1947,1950)$ correlated this work and tried to prove more conclusively the connection between pleurisy and tuberculous disease of the ribs and chest wall and of the spine. He was able to show experimentally in guinea pigs that particulate matter-a mixture of colloidal thorium dioxide and finely divided lamp black-or tubercle bacilli in suspension in isotonic saline, when injected into the pleural spaces, would in part at least be transported to the parasternal and the para-aortic lymph nodes. Observations in man, at necropsy, also showed that tubercle bacilli and particulate matter such as siliceous material were conveyed from the pleural spaces to these same two groups of glands. 
He suggested therefore that the occurrence of apparently spontaneous cold abscess of the chest wall really followed caseation of lymph nodes, rupture, and direct involvement of the chest wall with eventual burrowing of the cold abscess to the surface. He was not, however, able to demonstrate the production of a cold abscess of either the chest wall or spine in animals secondarily to post-pleuritic infection of lymph nodes; he was only able in 1940 to demonstrate a possible mode of spread of particulate matter.

$\mathrm{He}$ had carried the matter somewhat further by 1950 however. Among fourteen patients with abscess of the chest wall six had had previous pleurisy and ten had co-existing pleurisy; but nine of these fourteen patients had pulmonary tuberculosis, which might well have caused the pleurisy directly and he did not state how long before the appearance of the cold abscess the antecedent pleurisy had occurred. Therefore, although the sequence tuberculous pleurisy-caseous parasternal lymph gland-rib or chest wall abscess is not impossible, it cannot be said that Burke has shown that it occurs frequently or in what proportion it does occur. Burke also cited forty-five cases of Pott's disease studied from the Royal Victoria Hospital and the Montreal Neurological Institution between 1943 and 1950 in an attempt to prove that disease of the paravertebral space and the spine readily occurs as a result of caseation in overlying para-aortic glands. He listed eighteen patients with antecedent and twenty-one with co-existent pleurisy, some with both. But thirty of these also had pulmonary tuberculosis, which again bedevils the argument. Of the only four patients who had a co-existent pleurisy and Pott's disease, without pulmonary tuberculosis, three had disease in the mid-thoracic region and one had involvement of the first and second lumbar vertebrae with a paravertebral abscess which might well have spread both above and below the actual bone lesion. All these four cases would therefore confirm the findings in this paper: that co-existent effusion and Pott's disease affects one particular part of the spine-namely that in which the paravertebral abscess is in contact with the parietal pleura-and that the spread is from spine to pleura and not from pleura to spine. Furthermore, if the infection commonly spread from pleura to glands and thus to spine, the back spread to pleura again with consequent effusion would be most unlikely instead of frequent, because previous pleurisy would probably have produced adhesion between the parietal and visceral layers.

It cannot be denied from Burke's own work, and that of the other writers quoted, that lymphatic spread from an overlying caseous gland through the paravertebral ligaments may occasionally produce superficial disease of bone. But Burke goes on to say: " facts clearly point to the conclusion that Pott's disease is in many instances lymph-borne from tuberculous pleuritis "; and also claims that the experimental, anatomical and clinical findings recorded seem clearly to point to the conclusion that most cases of Pott's disease are the result of lymph-borne rather than blood-borne dissemination of tubercle bacilli. These statements are simply not justified by figures. The large number of cases of tuberculosis of bone in the limbs must be produced by haematogenous dissemination. It is equally likely that the same etiology is common in the axial skeleton and that Burke's conclusion upon Pott's disease is, in our present state of knowledge, an example of special pleading.

\section{SUMMARY}

1. Details are given of sixty-three consecutive cases with a history of pleural effusion seen at an orthopaedic hospital.

2. Twenty-four of these were post-primary effusions occurring before the onset of symptoms of the orthopaedic lesion. The bone and joint lesions ultimately developing in this group of patients were widely scattered throughout the skeleton.

3. Three others were secondary to adult-type pulmonary lesions.

4. Thirty-six patients had a pleural effusion after the beginning of their orthopaedic tuberculous history. Seven were certainly secondary to operative intervention, six in the 
thorax near the parietal pleura (costotransversectomy or antero-lateral decompression of the cord) and one from a haematogenous dissemination after fusion of a hip joint.

5. The remainder of this group with pleural effusion during the history of their orthopaedic tuberculous disease numbered twenty-nine. Of these, twenty-five suffered from disease of the thoracic spine; in two more details are defective. Only two definitely had neither pulmonary nor thoracic spinal disease; their lesions were in the lumbar spine.

The conclusion is drawn that the overwhelmingly common cause of pleural effusion in patients with orthopaedic tuberculosis who have normal lungs and have not recently suffered spinal decompression is transpleural infection from thoracic spinal disease and that the sequence is by no means rare. It had occurred in approximately one in six of $\mathbf{1 4 5}$ patients with thoracic Pott's disease seen during this investigation.

6. Details are given of a group of cases with thoracic paravertebral abscess tracking laterally. When the abscess is well clear of the spine and spinal ligaments it may project forwards and radiologically it may appear in the antero-posterior chest film as a shadow in the middle of one or other lung field rather than as a shadow obviously connected with the central paravertebral abscess. Aspiration will yield pus from this posterior extra-pleural abscess extension.

7. The belief that Pott's disease most commonly follows direct spread from caseous paraaortic glands secondary to tuberculous pleurisy is discussed. It is concluded that the evidence is insufficient for so sweeping a statement.

The patients in this survey have been under the care of my surgical colleagues on the staff of the Royal National Orthopaedic Hospital and I am grateful to them, as always, for their co-operation; and also to $\mathrm{Dr}$ E. H. Allen, Radiologist, and Dr. C. H. Lack, Bacteriologist to the hospital.

\section{REFERENCES}

Burke, H. E. (1940): The Role of Pleural Lymphatics in the Pathogenesis of Cold Abscesses of the Chest Wall and Paravertebral Abscesses. Journal of Thoracic Surgery, 9, 506.

Burke, H. E. (1940): A New Concept of the Sequelae of Tuberculous Pleurisy. New International Clinics, 4, 51 .

Burke, H. E. (1947): The Pathogenesis of Pott's Disease. Transactions of the American Clinical and Climatological Association, 59, 122.

Burke, H. E. (1950): The Pathogenesis of Certain Forms of Extra-pulmonary Tuberculosis. American Review of Tuberculosis, 62, 1-B. 48.

Fraser, J. (1913): An Experimental Study of Bone and Joint Tuberculosis. Journal of Experimental Medicine, 17, 362.

Fraser, J. (1929): Tuberculosis of the Spinal Column. Edinburgh Medical Journal, N.S. 36, 133.

Kaufmann, R. (1930): Pathogénie des abcès froids thoraciques. Paris: Amé dée Le Grand.

KaufmanN, R. (1931): Quelques considérations sur l'abcès thoracique. Journal de Chirurgie, 37, 829.

Kaufmann, R. (1933): De l'abcès froid thoracique. Annales d'Anatomie Pathologique, 10, 541.

Kaufmann, R. (1936): Anatomie pathologique et pathogénie du mal de Pott. Annales d'Anatomie Pathologique, 13, 81.

Marshall, Sir G., and Perry, K. M. A. (1952): Diseases of the Chest, Vol. 1, p. 358. London: Butterworth \& Co. (Publishers) Ltd.

Ornstein, G. G., and Ulmar, D. (1935): Tuberculous Caries of Vertebral Bodies. Quarterly Bulletin of Sea View Hospital, 1, 3.

Ornstein, G. G., and Ulmar, D. (1939): Tuberculous Empyema: Classification, Pathogenesis and Treatment. Quarterly Bulletin of Sea View Hospital, 4, 269.

Pagel, W., Simmonds, F. A. H., and Macdonald, N. (1953): Pulmonary Tuberculosis. Third edition, Chap. 8, p. 348. London: Geoffrey Cumberlege Oxford University Press.

Seddon, H. J. (1936): Fatal Case of Empyema Secondary to a Tuberculous Spinal Abscess. Proceedings of the Royal Society of Medicine (Section of Orthopaedics), 29, 1,662.

Souligoux, C. (1894): Pathogénie des abcès froids du thorax. Thèse de Paris.

vol. 37 B, NO. 1, FEBRUARY 1955 